\title{
COVER LAYERS TO THE GROWTH OF TREES AND SHROBS OVER A SULFIDE SPOIL FROM GOLD MINING ${ }^{1}$
}

Igor Rodrigues de Assis², Luiz Eduardo Dias², Walter Antônio Pereira Abrahão², Emerson Silva Ribeiro $\mathrm{Jr}^{3}$ e Jaime Wilson Vargas de Mello²

\begin{abstract}
This work was done at a gold mine company in Paracatu, MG, Brazil, and was conducted from March 2000 to November 2005. The substrate (spoil) studied was a phillite rock which contains sulfides such as pyrite and arsenopyrite. This study aimed to evaluate the survival and growth of plant species on different combinations of substrate layers over the spoil. These layers were a cover layer and a sealing layer, both deposited over the spoil. The treatment 1 had saprolite (B1) in the sealing layer (SL) and B1 with liming (B1L) in the cover layer (CL). The treatment 2 had B1 in SL and B1L + soil with liming (SoL) in the CL. The treatment 3 had B1 + SoL in the SL and B1L in the CL. The treatment 4 had B1 + SoL in the SL and $\mathrm{B} 1 \mathrm{~L}+\mathrm{SoL}$ in the CL. The plant species used were Acacia farnesiana, A. holosericea, A. polyphylla, Albizia lebbeck, Clitoria fairchildiana, Flemingia sp., Mimosa artemisiana, M. bimucronata e Enterolobium contortisiliquum. Forty and 57 months after planting, collardiameter, height, and living plants were evaluated. The greatest survival rate was oobservedintreatmentwith B horizon of an Oxisoil in both layers, with $80 \%$. In general, M. bimucronata and A. farnesiana species showed the highest survival rate. The arsenic-content by Mehlich 3 in the cover layer ranged from 0.00 to $14.69 \mathrm{mg} \mathrm{dm}^{-3}$ among treatments. The experimental results suggest that layers combinations above the sulfide substrate allow the rapid revegetation of the spoil.
\end{abstract}

Keywords: Sulfide substrate, Reforestation and Land reclamation.

\section{CAMADAS DE COBERTURA PARA O CRESCIMENTO DE ÁRVORES E ARBUSTOS SOBRE UM SUBSTRATO SULFETADO DE MINERAÇÃO DE OURO}

\begin{abstract}
RESUMO - Este trabalho foi desenvolvido em área de mineração de ouro no Município de Paracatu, MG, Brasil, durante o período de março de 2000 a novembro de 2005. O substrato estudado foi um filito que contém sulfetos como pirita e arsenopirita. O objetivo deste trabalho foi avaliar a sobrevivência e crescimento de espécies vegetais sobre diferentes combinações de camadas de cobertura e de selamento sobre um substrato sulfetado. O tratamento 1 possuía saprolito (B1) na camada selante (SL) e B1 com calagem (B1L) na camada de cobertura (CL). O tratamento 2 possuía B1 na SL e B1L + solo com calagem (SoL) como CL. O tratamento 3 possuía B1 + SoL como SL e B1L como CL. O tratamento 4 possuía B1 + SoL como SL e B1L + SoL como $C L$. As espécies utilizadas foram Acacia farnesiana, A. holosericea, A. polyphylla, Albizia lebbeck, Clitoria fairchildiana, Flemingia sp., Mimosa artemisiana, M. bimucronata e Enterolobium contortisiliquum. Aos 40 e 57 meses após o plantio foram avaliados diâmetro do colo, altura e contagem das plantas vivas. A maior taxa de sobrevivência (80\%) foi observada no tratamento com presença de horizonte B latossólico nas camadas selante e cobertura. De modo geral, M. bimucronata e A. farnesiana mostraram as mais altas taxas de sobrevivência. A teor de arsênio extraído por Mehlich 3 na camada de cobertura variou de 0,00 a 14,69 $\mathrm{mg} \mathrm{dm}^{-3}$ entre os tratamentos. Os resultados indicaram que a utilização de diferentes camadas sobre o substrato sulfetado permite a rápida revegetação da área remanescente de mineração.
\end{abstract}

Palavras-chave: Substrato sulfetado, Revegetação e Recuperação de áreas degradadas.

\footnotetext{
${ }^{1}$ Recebido em 06.04.2009 e aceito para publicação em 20.04.2011.

22Departamento de Solos, Universidade Federal de Viçosa, UFV, Brasil.E-mail:<igor.assis@ufv.br>, <ledias@ufv.br>,<wabrahao@ufv.br> e<jwvmello@ufv.br>.

${ }^{3}$ Conselho Nacional de Desenvolvimento Científico e Tecnológico, CNPq. E-mail: <eribeiro@cnpq.br>.
} 


\section{INTRODUCTION}

The recovery of areas degraded by mining usually involves the restoration of vegetation, but this process is rarely monitored in an appropriate manner (ALMEIDA et al., 2005).

There are many parameters that can be used as indicators of the recovery process, but the great challenge is to develop or adapt valid criteria to monitor and evaluate the functionality of the area, as well as discriminating indicators that provide the desired information with accuracy and acceptable cost. Specific indicators must be developed for each individual situation and environment, as it is difficult to develop universal indicators (RODRIGUES; GANDOLFI, 2001).

Reforestation efforts may be further complicated by the presence of sulfides in mineral rocks, which can lead to the formation of acid mine drainage and the consequent release of heavy metals and metalloids into the environment (DIAS et al., 1999; MELLO et al., 2003). This includes arsenic (As), which is currently considered the most hazardous substance to human health (ATSDR, 2008).

There is a world tendency in to use cover layers over sulfide substrates of mining activities, allowing the reforestation (SUNDBLAD, 2003; SAGHAFI, 2010). Sealing layer is use to reduce water infiltration and consequently to minimize the substrate oxidation and, over sealing layer, a cover layer with better conditions for the reforestation was suggested by Dias et al. (2008).

Experimental results in the controller environment using sulfide substrate of gold mining, from Paracatu, MG, showed the necessity to use these layers to decrease the mobilization of elements solubilized by the oxidation of the substrate. Furthermore, it was tested the use an additional layer with chemical treatments, called geochemical barrier, showed the best results to decrease As, Fe and S mobilization (ASSIS, 2006). However, these additional treatments have not been tested in field condictions, it might contribute to advance of reforestation programs of areas with sulfide substrate.

Beside the favorable effects of the cover layers to allow the establishment and growth of plants (DIAS et al., 1999), trials to select more number of species with potential to reforestation sulfide substrates, it is also very important to guarantee the sustainability of these areas. Thus, this study aimed to evaluate the survival and growth of plant species on different combinations of substrate layers over the sulfide substrate remaining mining (spoil).

\section{MATERIALAND METHODS}

The field experiment was carried out at a gold mine located in Paracatu, in the State of Minas Gerais, Brazil. It was assembled in March 2000 and dismantled in November 2005. Four lanes, five meters wide and twenty meters long, were built and divided into three parts, constituting three replications. These tracks were made of different materials and arranged above the somewhat weathered sulfide substrate, constituting the four tested treatments (Figure 1). The materials used were: rather weathered sulfide substrate (saprolite - B1) and B horizon of Oxisol (soil). Treatments: (T1) a cover layer with 50 cm of B1 with lime underneath a compacted sealing layer with $30 \mathrm{~cm}$ of B1; (T2) cover layer with $25 \mathrm{~cm}$ of B1 with lime $+25 \mathrm{~cm}$ of soil with lime underneath a compacted sealing layer with $30 \mathrm{~cm}$ of B1; (T3) cover layer with $50 \mathrm{~cm}$ of B1 with lime underneath a compacted sealing layer with $20 \mathrm{~cm}$ of B1 $+20 \mathrm{~cm}$ of soil with lime; (T4) cover layer with $25 \mathrm{~cm}$ of B1 with lime $+25 \mathrm{~cm}$ of soil with lime underneath a compacted sealing layer with $20 \mathrm{~cm}$ of B1 $+20 \mathrm{~cm}$ of soil with lime. In the month of May 2000 the monitoring of the experiment was initiated.

For the construction of the sealant layer, the materials were disposed in the area and compacted using a mechanical compactor to maximum compression.

Each experimental plot received the planting of nine species of leguminous tree or shrub (a spacing of $1.0 \times 1.0 \mathrm{~m}$.). The planting was carried out as a sequence

(1) Sealing Layer

(2) Coverage Layer

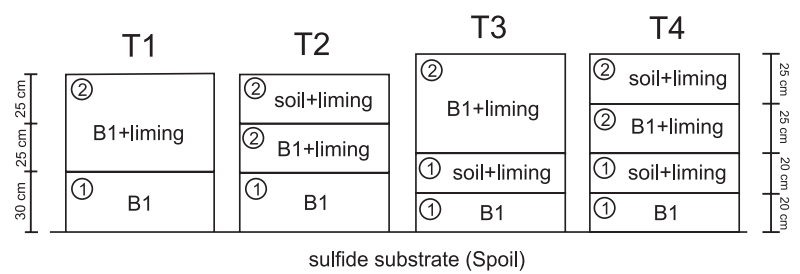

Figure 1 - Description of the treatments. B1: rather weathered sulfide substrate; Soil: B horizon of Oxisol (clay soil). The sealing layer was compressed.

Figura 1 -Descrição dos tratamentos. B1: substrato sulfetado bastante intemperizado; Soil: horizonte B de um Latossolo (solo argiloso). A camada selante foi compactada. 
of six plants of the same species in a row, until the plants of the nine species were planted and then, start up a new replication with six plants of each species.

Initial fertilization was carried out in a hole (30.0 cm wide by $40.0 \mathrm{~cm}$ deep) with $150.0 \mathrm{~g}$ of rock phosphate, $50.0 \mathrm{~g}$ of $\mathrm{KCl}$ and $1.0 \mathrm{~L}$ of previously tanned cattle manure. The following species were used: Acacia farnesiana (L.) Willd., Acacia holosericea, Acacia polyphylla DC., Albizia lebbeck (L.) Bentham, Clitoria fairchildiana, Flemingia Sp., Mimosa artemisiana, Mimosa bimucronata (DC.) Kuntze and Enterolobium contortisiliquum.

Two evaluations of plant survival and growth were completed, the first in August 2003 (forty months after the planting time) and the second in January 2005 (17 months after the first evaluation). Plant growth was evaluated (biometrics analysis) with values of the collar diameter (CD) and height of each plant, disregarding those present at the edges. 162 plants were evaluated in each treatment: 54 per block, with six individuals of each species. Arsenic levels were measured in samples collected from the substrate cover layer $(0-20 \mathrm{~cm})$ using the extractor Mehlich III (MEHLICH, 1984).

Statistical analysis was performed to verify, in the variance analysis, the homogeneity of variances for the different treatments under study. The degrees of freedom for treatments were deployed in orthogonal contrasts + additional contrasts, not necessarily orthogonal with all other contrasts (ALVAREZ V.; ALVAREZ, 2006).

To analyze the effect of treatments on the growth of the species, statistical analysis of contrasts for the two assessments made was used, with no orthogonality between them. For both assessments, the average values of the collar diameter (CD) and plantheight (H) of all species were taken. In the second evaluation, as the treatment one showed a $100 \%$ mortality, it was possible to establish only two contrasts.

The evaluation the growth of species was made firstly by the general average of the species, comparing the effects of treatments and after by general average of the treatments, comparing the effects of species. For evaluation of the species, they were grouped by the Scott - Knott test of $5 \%$ probability.

\section{RESULTS}

In the first evaluation ( $40^{\text {th }}$ month), 69 plants survived in treatment 1 - a rate of approximately $43 \%$. None of the Clitoria fairchildiana, Flemingia and Acacia sp polyphylla species survived (Table 1). Albizia lebbeck and Acacia farnesiana species obtained a higher survival rate, in the average of all treatments, with values equal to 93 and $94 \%$ respectively. The lowest survival rates,

Table 1 - Survival percentage of the species used in the revegetation experiment of sulfide spoil mining, located in ParacatuMG, in the evaluations conducted at 40 and 57 months after planting.

Tabela 1 - Percentagens de sobrevivência das espécies utilizadas no experimento de revegetação de material sulfetado remanescente de mineração, localizado no município de Paracatu-MG, na avaliações aos 40 e 57 meses após o plantio.

\begin{tabular}{|c|c|c|c|c|c|c|c|c|}
\hline \multirow[t]{3}{*}{ Specie } & \multicolumn{8}{|c|}{ Survival } \\
\hline & \multicolumn{2}{|c|}{ Treatment 1} & \multicolumn{2}{|c|}{ Treatment 2} & \multicolumn{2}{|c|}{ Treatment 3} & \multicolumn{2}{|c|}{ Treatment 4} \\
\hline & 40 & 57 & 40 & 57 & 40 & 57 & 40 & 57 \\
\hline & & & & $\%$ & & & & \\
\hline A. farnesiana & 83.3 & 0.0 & 100 & 94.4 & 100 & 100 & 94.4 & 88.9 \\
\hline A. holosericea & 33.3 & 0.0 & 83.3 & 83.3 & 100 & 94.4 & 88.9 & 88.9 \\
\hline A. polyphylla & 0.0 & 0.0 & 61.1 & 61.1 & 77.8 & 77.8 & 88.9 & 72.2 \\
\hline A. lebbeck & 88.9 & 0.0 & 88.9 & 83.3 & 100 & 100 & 94.4 & 88.9 \\
\hline C. fairchildiana & 0.0 & 0.0 & 33.3 & 0.0 & 72.2 & 33.3 & 94.4 & 50.0 \\
\hline Flemingia sp. & 0.0 & 0.0 & 0.0 & 0.0 & 11.1 & 0.0 & 50.0 & 50.0 \\
\hline M. artemisiana & 44.4 & 0.0 & 72.2 & 50.0 & 88.9 & 50.0 & 94.4 & 88.9 \\
\hline M. bimucronata & 66.7 & 0.0 & 94.4 & 88.9 & 100 & 100 & 100 & 94.4 \\
\hline E. contortisiliquum & 66.7 & 0.0 & 61.1 & 61.1 & 100 & 88.9 & 100 & 94.4 \\
\hline Overall Average & 42.6 & 0.0 & 66.1 & 58.0 & 83.3 & 71.6 & 89.5 & 79.6 \\
\hline
\end{tabular}


in the average of all treatments, were observed in the Flemingia sp. and Clitoria fairchildiana species, with 15 and 50\%, respectively.

In the second evaluation in January 2005, no plants were observed to survive in treatment 1 . The survival percentage of the species for treatments 2, 3 and 4 were higher (Table 1). The lowest survival percentage, in the average of all treatments, were the same for species, but the Mimosa bimucronata and Acacia farnesiana species stood out with the highest survival rates. In these treatments the soil was present in any of the layers.

Treatment 4 provided greater growth of the species used (Table 2). The average values of CD were equal to $33.94 \mathrm{~mm}$ in the first evaluation and $38.40 \mathrm{~mm}$ in the second evaluation. This represents a CD average growth rate of $3.14 \mathrm{~mm} \mathrm{yr}^{-1}$. The average plant height was $167.67 \mathrm{~cm}$ in the first evaluation and $208.31 \mathrm{~cm}$ in the second, representing annual growth rate of 28.69 $\mathrm{cm}$. However, there was great growth differentiation among the species tested.

According to the test group Scott - Knott, A. holosericea stands, with higher CD and plant height values in both evaluations. The species A. polyphylla and $A$. lebbeck showed the lowest growth among the species tested.

Table 2 - Mean values of collar diameter (CD) and plant height $(\mathrm{H})$ for the different treatments in the experiment established about revegetation of sulfide spoil mining at 40 and 57 months after planting.

Tabela 2 - Valores médios de diâmetro do colo (CD) e altura de planta $(H)$ para os diferentes tratamentos estabelecidos no experimento sobre revegetação de substrato sulfetado remanescente de mineração aos 40 e 57 meses após o plantio.

\begin{tabular}{ccccc}
\hline Treatment & \multicolumn{3}{c}{ CD } & \multicolumn{2}{c}{$\mathrm{H}$} \\
\cline { 2 - 6 } & $40^{\text {th }}$ & $5^{\text {th }}$ & $47^{\text {th }}$ \\
\hline & \multicolumn{3}{c}{$\mathrm{mm}$} & \multicolumn{3}{c}{$\mathrm{Cm}$} \\
2 & 28.53 & $-^{1 /}$ & $129.55^{-1 /}$ & $-^{1 /}$ \\
3 & 35.63 & 32.93 & 164.16 & 196.04 \\
4 & 33.93 & 38.10 & 176.42 & 201.88 \\
\hline
\end{tabular}

\section{DISCUSSION}

Treatment one consisted of B1 as both the sealing and cover layer, with lime in the first layer and compaction the second. The formation of salt crusts was noted on the surface of this treatment, with the highest observed levels of available arsenic (Mehlich 3), averaging $14.69 \mathrm{mg} \mathrm{kg}^{-1}$, so no plants survived in this treatment. The average levels of available arsenic in the cover layer samples of treatments two, three and four were $0.0,10.41$ and $0.00 \mathrm{mg}$ $\mathrm{kg}^{-1}$, respectively; however the presence of salt crusts was not observed on the surface of treatment three. Thus, the salt formation (high electrical conductivity) was probably not the only cause for the death of all individuals in treatment one.

\subsection{First evaluation (40 months after planting)}

According to the $\mathrm{C}_{1}$ contrast (Table 3 ), there was greater growth of plants, regardless of species, in treatment two compared with treatment one. The CD was, on average, $7.10 \mathrm{~mm}$ higher $(\mathrm{p}<0.05)$ and the median plant height was $34.6 \mathrm{~cm}$ higher $(\mathrm{p}<0.1)$. There was, therefore, a positive effect of soil + liming, providing better conditions for the growth of plants of different species.

The positive effect of the soil can also be observed in the sealing layer, where their presence has provided greater growth of plants, regardless of the cover layer. When compacted soil + liming were used together with the $\mathrm{B} 1$ substrate in the sealing layer (contrast $\mathrm{C}_{2}$ ), the CD was on average $3.72 \mathrm{~mm}$ higher $(\mathrm{p}<0.1)$ and the plant height was $41.62 \mathrm{~cm}$ higher $(\mathrm{p}<0.01)$. According to the $\mathrm{C}_{3}$ contrast, even the cover layer is composed only with B1 + lime, the presence of compacted soil + liming in the sealing layer provided better conditions for plant growth, once CD was, on average, $5.40 \mathrm{~mm}$ higher $(\mathrm{p}<0.1)$ and the height was $46.87 \mathrm{~cm}$ higher $(\mathrm{p}<0.05)$.

When compacted soil + liming were used together with the B1 substrate in the sealing layer and compared to its presence or not in the cover layer $\left(\mathrm{C}_{4}\right.$ contrast), there was no significant difference between treatments for CD and plant height. This suggests that the combination of materials in the sealant layer was more effective for plant establishment compared to the material used in the same layer of the treatments one and two. When soil + liming was present in the cover layer and the presence of compacted soil + liming in the sealing layer was varied, there was no significant difference between treatments for $\mathrm{CD}$, but the average plant height was $36.37 \mathrm{~cm}(p<0,1)$ higher when the soil was present in the sealing layer ( $C_{5}$ contrast). 
Table 3 - Average contrasts for collar diameter (CD) and height of the plants used in the revegetation experiment of sulfide spoil mining, located in Paracatu-MG, in the evaluation conducted at 40 months after planting.

Tabela 3 - Contrastes médios para diâmetro do colo (CD) e altura das plantas utilizadas no experimento de revegetação de material sulfetado remanescente de mineração, localizado no município de Paracatu-MG, na avaliação aos 40 meses após o plantio.

\begin{tabular}{lcccccc}
\hline Source & $\mathrm{C}_{1}$ & $\mathrm{C}_{2}$ & $\mathrm{C}_{3}$ & $\mathrm{C}_{4}$ & $\mathrm{C}_{5}$ & $\mathrm{C}_{6}$ \\
\hline $\mathrm{CD}(\mathrm{mm})$ & $7.10^{*}$ & $3.72^{\circ}$ & $5.40^{\circ}$ & 3.73 & 2.03 & $5.41^{*}$ \\
Height $(\mathrm{cm})$ & $34.61^{\circ}$ & $41.62^{* *}$ & $46.87^{*}$ & 24.11 & $36.37^{\circ}$ & $29.36^{*}$ \\
\hline
\end{tabular}

Regardless of the combination used in the sealing layer, the presence of soil + liming in the cover layer, compared with the use of the B1 substrate + liming only $\left(\mathrm{C}_{6}\right.$ contrast), provided greater growth of plants. The relatively minor differences observed confirm the greater importance of soil in the sealing layer than the cover layer.

\subsection{Second evaluation (at 57 months after planting)}

In this evaluation, no plants in treatment one survived, andonly the effect of the compacted soil with liming in the sealing layer could be observed by the contrasts. Considering the others treatments, the presence of soil in the sealing layer gave significant biomass increase; the average CD was $11.25 \mathrm{~mm}$ higher $(\mathrm{p}<0.05)$ (Table 4) and the plant height was $30.98 \mathrm{~cm}$ higher ( $<<0.05$ ) in the presence of the compacted B1 substrate.

The same effect was observed in the cover layer, where there was significant biomass increase in the soil + B1 substrate + liming in the cover layer mixture when compared with the B1 substrate only. In this case, the sealing layer was composed by substrate B1+ compacted soil liming.

Table 4 - Average contrasts for collar diameter (CD) and height of the plants used in the revegetation experiment of sulfide spoil mining, located in ParacatuMG, in the evaluation conducted at 57 months after planting.

Tabela 4 - Contrastes médios para diâmetro do colo (CD) e altura das plantas utilizadas no experimento de revegetação de material sulfetado remanescente de mineração, localizado no município de ParacatuMG, na avaliação aos 57 meses após o plantio.

\begin{tabular}{ccc}
\hline Source & $\mathrm{C}_{1}$ & $\mathrm{C}_{2}$ \\
\hline $\mathrm{CD}(\mathrm{mm})$ & $6.08^{*}$ & $11.25^{* *}$ \\
Height $(\mathrm{cm})$ & $25.14^{\circ}$ & $30.98^{*}$ \\
\hline
\end{tabular}

$\mathrm{C}_{1}$ : T3 vs T4; $\mathrm{C}_{2}$ : T2 vs T4.

$\circ, *, * *$ : Significant at 10,5 e $1 \%$, respectively, by the $\mathrm{F}$ test.
The presence of soil with liming in the cover layer and compacted soil with liming in the sealing layer (T4) showed the best results for plant growth, regardless of the species used. However, a more intensive effect was observed when it was present in the sealing layer, suggesting an interesting practice for reforestation of these environments.

\subsection{Evaluation of Species}

The species able to produce large quantities of biomass are the most interesting to start the vegetation program to create better soil conditions to the sucessional process. In this sense, Acacia holosericea stands out with the highest values of CD and plant height, forming the first group alone, by the Scott Knott test (Tables 5 and 6).

In both evaluations large differences on the growth were observed among species, which were divided up into five separate groups. The lower biomass production was observed in the Enterolobium contortisiliquum, Flemingia sp. and Acacia polyphylla species. Otherwise, these species could be used to improve the biological diversity of the reforestation program.

Over the study period, $A$. holosericea showed a CD growth rate of about $13.0 \mathrm{~mm} \mathrm{yr}^{-1}$. In this same period, there was no CD growth from the species with lower biomass production. Similar behavior was observed for plant height, with growth rate of $58.89 \mathrm{~cm} \mathrm{yr}^{-1}$ to A. holosericea.

Acacia holosericea responded to the differences in treatment in both evaluations (Tables 5 and 6). Except for the treatment 1 , the survival rate of this specie did not vary greatly under different treatments. This species is indicator to reforestation of degradation lands due its capacity to associate with diazotropic bacteria and growth in low fertility conditions (BALIEIRO, 2001). Furthermore, this species has a great litter production and activity of soil fauna under their canopy.

Revista Árvore, Viçosa-MG, v.35, n.4, p.941-947, 2011 
Table 5 - Average collar diameter (CD) and average plant height (H) results for each treatment for the nine species at 40 months after planting.

Tabela 5 - Resultados médios de diâmetro de colo (CD) e altura das plantas em cada tratamento para as nove espécies aos 40 meses após o plantio.

\begin{tabular}{|c|c|c|c|c|c|c|c|c|}
\hline \multirow[t]{2}{*}{ Specie } & \multicolumn{2}{|c|}{ Treatment 1} & \multicolumn{2}{|c|}{ Treatment 2} & \multicolumn{2}{|c|}{ Treatment 3} & \multicolumn{2}{|c|}{ Treatment 4} \\
\hline & CD & $\mathrm{H}$ & CD & $\mathrm{H}$ & $\mathrm{CD}$ & $\mathrm{H}$ & CD & $\mathrm{H}$ \\
\hline & $\mathrm{mm}$ & $\mathrm{cm}$ & $\mathrm{mm}$ & $\mathrm{cm}$ & $\mathrm{mm}$ & $\mathrm{cm}$ & $\mathrm{mm}$ & $\mathrm{cm}$ \\
\hline A. farnesiana & $18.59 b$ & 129.1b & $29.93 c$ & $182.2 b$ & $28.20 c$ & $174.6 \mathrm{c}$ & $36.76 \mathrm{c}$ & $222.5 c$ \\
\hline A. holosericea & $56.38 a$ & $234.2 \mathrm{a}$ & $68.48 a$ & $299.7 a$ & $75.92 \mathrm{a}$ & $298.3 a$ & $87.21 \mathrm{a}$ & $346.5 a$ \\
\hline A. polyphylla & - & - & $14.52 \mathrm{c}$ & $113.9 b$ & $13.93 d$ & $128.8 d$ & $9.44 \mathrm{e}$ & $87.56 \mathrm{~d}$ \\
\hline A. lebbeck & $26.44 b$ & $98.6 b$ & $28.89 c$ & $127.8 b$ & $48.20 \mathrm{~b}$ & $206.8 b$ & $43.24 c$ & $192.0 \mathrm{c}$ \\
\hline C. fairchildiana & - & - & $39.47 c$ & $60.2 \mathrm{c}$ & $33.95 c$ & $92.0 d$ & $35.34 c$ & $118.5 d$ \\
\hline Flemingia sp. & - & - & - & - & $9.45 \mathrm{~d}$ & $90.0 d$ & $15.62 d$ & $171.0 \mathrm{c}$ \\
\hline M. artemisiana & $19.53 b$ & $91.0 \mathrm{~b}$ & $20.93 c$ & $127.2 b$ & $21.82 \mathrm{c}$ & $140.9 \mathrm{c}$ & $35.65 c$ & $209.8 c$ \\
\hline M. bimucronata & $48.66 a$ & $199.2 \mathrm{a}$ & $53.35 b$ & $239.5 a$ & $41.05 b$ & $242.3 b$ & $53.48 b$ & $286.3 b$ \\
\hline E. contortisiliquum & $13.04 b$ & $91.6 b$ & $22.37 c$ & $119.7 b$ & $21.84 c$ & $165.2 \mathrm{c}$ & $21.57 d$ & $157.6 \mathrm{c}$ \\
\hline
\end{tabular}

Averages followed by the same letter in the columns do not differ from each other, by the Scott-Knott test group at $5 \%$ probability.

Table 6 - Average collar diameter (CD) and average plant height (H) results for each treatment for the nine species at 57 months after planting.

Tabela 6 - Resultados médios de diâmetro de colo (CD) e altura das plantas em cada tratamento para as nove espécies aos 57 meses após o plantio.

\begin{tabular}{|c|c|c|c|c|c|c|c|c|}
\hline \multirow[t]{2}{*}{ Specie } & \multicolumn{2}{|c|}{ Treatment 1} & \multicolumn{2}{|c|}{ Treatment 2} & \multicolumn{2}{|c|}{ Treatment 3} & \multicolumn{2}{|c|}{ Treatment 4} \\
\hline & $\mathrm{CD}$ & $\mathrm{H}$ & $\mathrm{CD}$ & $\mathrm{H}$ & $\mathrm{CD}$ & $\mathrm{H}$ & $\mathrm{CD}$ & $\mathrm{H}$ \\
\hline & $\mathrm{mm}$ & $\mathrm{cm}$ & $\mathrm{mm}$ & $\mathrm{cm}$ & $\mathrm{mm}$ & $\mathrm{cm}$ & $\mathrm{mm}$ & $\mathrm{cm}$ \\
\hline A. farnesiana & - & - & $29.25 c$ & $188.4 \mathrm{C}$ & $30.05 c$ & $173.6 \mathrm{c}$ & $42.19 c$ & $237.1 \mathrm{c}$ \\
\hline A. holosericea & - & - & $75.85 a$ & $383.5 a$ & $87.45 a$ & $360.2 a$ & $107.9 a$ & $390.6 a$ \\
\hline A. polyphylla & - & - & $13.22 \mathrm{c}$ & $137.8 \mathrm{c}$ & $11.68 d$ & $128.6 \mathrm{~d}$ & $9.91 \mathrm{e}$ & $96.9 \mathrm{~d}$ \\
\hline A. lebbeck & - & - & $28.97 c$ & $129.0 \mathrm{c}$ & $49.23 b$ & $199.7 \mathrm{C}$ & $43.21 \mathrm{c}$ & $202.9 c$ \\
\hline C. fairchildiana & - & - & - & - & $29.20 c$ & $95.5 d$ & $47.02 \mathrm{c}$ & $189.2 \mathrm{c}$ \\
\hline Flemingia sp. & - & - & - & - & - & - & $23.57 d$ & $177.0 \mathrm{c}$ \\
\hline M. artemisiana & - & - & $21.50 \mathrm{c}$ & $117.8 \mathrm{c}$ & $27.60 \mathrm{c}$ & $218.0 c$ & $42.24 c$ & $278.9 b$ \\
\hline M. bimucronata & - & - & $43.64 b$ & $274.1 b$ & $39.54 b$ & $256.6 b$ & $60.00 \mathrm{~b}$ & $301.9 b$ \\
\hline E. contortisiliquum & - & - & $18.37 \mathrm{C}$ & $126.4 \mathrm{c}$ & $21.66 \mathrm{~d}$ & $167.7 \mathrm{C}$ & $20.45 d$ & $169.7 \mathrm{C}$ \\
\hline
\end{tabular}

Averages followed by the same letter in the columns do not differ from each other, by the Scott-Knott test group at $5 \%$ probability.

Generally, the Clitoria fairchildiana, Acacia polyphylla and Enterolobium contortisiliquum species were not sensitive to the treatments, neither for growth nor for survival. The other species have shown different responses to the treatments and appear to be sensitive to changes in the substrate. Flemingia sp. specifically proved to be very sensitive.

Also, the largest growth of Acacia farnesiana and Mimosa artemisiana species was observed in treatment four (Table 1); growth was significantly lower in other treatments. In addition, Fernández et al. (1996), working with Mimosa tenuiflora, showed this specie had good response to increasing of liming and fertilization.
The use of layers on sulfide material for vegetation establishment was studied by Dias et al. (1999, 2000). According to this author, the absence of these layers makes the process of reforestation of these areas very difficult. In its preliminary studies, the planting of crops suffer this substrate provided directly the death of all individuals.

\section{CONCLUSION}

The simple use of cover layers above the sulfide substrate has not ensured the establishment and good growth of plants tested. The addition of soil in at least one of these layers provided the greatest survival rates and the highest growth for all tested species.

Revista Árvore, Viçosa-MG, v.35, n.4., p.941-947, 2011 
Among the studied species, Acacia holosericea had the highest biomass production. In contrast, the lowest production was observed in the Enterolobium contortisiliquum, Flemingia sp. and Acacia polyphylla species. Although the Acacia holosericea had higher biomass production, it was more sensitive to different types of materials that formed the cover layers.

\section{ACKNOWLEDGEMENTS}

This study was supported by The National Council for Scientific and Technological Development (CNPq).

\section{REFERENCES}

ALMEIDA, R. O. P. O.; SÁNCHEZ, L. H. Revegetação de áreas de mineração: critérios de monitoramento e avaliação do desempenho. Revista Árvore, v.29, n.1, p.47-54, 2005.

ALVAREZ V., V. H. \& ALVAREZ, G. A. M. Comparação de médias ou teste de hipóteses? Contrastes! Boletim Informativo da SBCS, v.31, p.:24-34, 2006.

ASSIS, I. R. Mitigação da lixiviação de arsênio, ferro e enxofre e revegetação de substratos minerados em área de ocorrência de drenagem ácida. 2006. $90 \mathrm{f}$. Dissertação (Mestrado em Solos e Nutrição de Plantas) - Universidade Federal de Viçosa, Viçosa, MG, 2006.

AGENCY FOR TOXIC SUBSTANCES \& DISEASE REGISTRAY - ATSDR. CERCLA Priority List of Hazardous Substances. Available in: <http://www.atsdr.cCD.gov/cercla/07list.html>. Assessed in: June, 28th 2008.

BALIEIRO, F. C.; OLIVEIRA, I. G.; DIAS, L. E. Formação de mudas de Acacia holosericea e A. auriculiformis: resposta a calagem, fósforo, potássio e enxofre. Revista Árvore, v.25, n.2, p.183-191, 2001.

DIAS, L. E.; ASSIS, I. R.; DANIELS, W. L. Revegetation of acid forming mine spoil in Paracatu, Minas Gerais State, Brazil. In: NATIONAL MEETING OF THE AMERICAN SOCIETY OF MINING AND RECLAMATION, 2008, Richmond: New opportunities to apply our science. American Society of Mining and Reclamation, 2008.
DIAS, L. E. et al. Initial growth of leguminus trees and shrubs in a cut gold mined area in Minas Gerais State, Brazil. In: AMERICAN SOCIETY FOR SURFACE MINING AND RECLAMATION. ANNUAL NATIONAL MEETING,16, lexington, 1999. Proceedings... Lexington: 1999.v.1. p.316-321.

DIAS, L. E. et al. Reconstrução topográfica e crescimento de leguminosas arbóreas e arbustivas em substrato contendo sulfetos metálicos In: SIMPÓSIO NACIONAL DE RECUPERAÇÃO DE ÁREAS DEGRADADAS, 4., 2000, Blumenau. Anais... Blumenau: 2000. p.114. CD ROM.

FERNANDEZ, J. Q. P. et al. Crescimento de mudas de mimosa tenuiflora submetidas a diferentes níveis de calagem e doses de fósforo, potássio e enxofre. Revista Árvore, v.20, n.4, p.425-432, 1996.

MEHLICH, A. Mehlich 3 soil test extractant a modification of Mehlich 2 extractant.

Communications in Soil Science and Plant Analysis, v.15, n.2, p.1409-1416, 1984.

MELLO, J. W. V.; DIAS, L. E.; CORREA, M. L. T. Drenagem ácida: avaliação do potencial de ocorrência, mitigação e revegetação de substratos sulfetados. In: ALVAREZ V., V .H. et al.; LOPES, A. S.; LIMA, J. M.; GUILHERME, L. R. G.; MARQUES, J. J.; NILTON CURI, N., (Eds). Tópicos em ciência do solo. Viçosa, MG: Sociedade Brasileira de Ciência do Solo, 2003. v.3. 430p.

RODRIGUES, R.; GANDOLFI, S. Conceitos tendências e ações para a recuperação de florestas ciliares. In: RODRIGUES, R. R.; LEITÃO FILHO, H. R. (Ed.). Matas ciliares: conservação e recuperação. 2.ed. São Paulo: Edusp, 2001. p. 235-247.

SAGHAFI, A.; CARRAS, J. N. Assessment of the effectiveness of inert cover layers to control theheating of spoil-piles in open cut coal mines. In: INTERNATIONAL PITTSBURGH COAL CONFERENCE, 2010, Istanbul. Proceedings... Istanbul: 2010.

SUNDBLAD, B. Ten years experience of a multilayer cover system for uranium mill tailings in Ranstad Sweden. In: CONFERENCE MINING AND THE ENVIRONMENT, 3., 2003, Sudbury. Proceedings... Sudbury: 2003.

Revista Árvore, Viçosa-MG, v.35, n.4, p.941-947, 2011 
